\title{
Benign Cecum Neoplasm
}

National Cancer Institute

\section{Source}

National Cancer Institute. Benign Cecum Neoplasm. NCI Thesaurus. Code C4772.

A non-metastasizing neoplasm arising from the wall of the cecum. 